\title{
KEEFEKTIFAN MODEL PROBLEM BASED LEARNING TERHADAP KEMAMPUAN PROSES SAINS
}

\author{
Triman Juniarso \\ Universitas PGRI Adi Buana Surabaya \\ triman@unipasby.ac.id
}

\begin{abstract}
ABSTRAK
Kemampuan Proses Sains dibutuhkan untuk menghadapi tantangan globalisasi. Namun, banyak calon guru sekolah dasar yang masih rendah kemampuan proses sainsnya. Salah satu upaya memperbaiki kemampuan proses sains melalui penerapan model pembelajaran Problem Based Learning (PBL). Penelitian ini dilakukan untuk mengetahui keefektifan model PBL terhadap kemampuan literasi sains. Penelitian ini merupakan penelitian eksperimental. Metode yang digunakan adalah tes dan observasi. Hasil penelitian menyatakan bahwa model PBL efektif terhadap kemampuan literasi sains. Keefektifan ditunjukkan dari hasil tes dan observasi aktivitas mahasiswa.

Katakunci : kemampuan proses, problem based learning, sains.

\section{ABSTRACT}

The ability of the Science Process is needed to face the challenges of globalization. However, many elementary school teacher candidates are still low in science process capability. One effort to improve the ability of the science process through the application of the Problem Based Learning (PBL) learning model. This research was conducted to determine the effectiveness of the PBL model on the ability of scientific literacy. This research is an experimental research. The method used is a test and observation. The results of the study stated that the PBL model was effective in the ability of scientific literacy. The effectiveness is shown from the results of tests and observations of student activities.
\end{abstract}

Keywords : process ability, problem based learning, sains.

\section{PENDAHULUAN}

Pendidikan merupakan salah satu upaya memperbaiki kualitas diri manusia. Implementasi nyata proses pendidikan melalui pembelajaran di setiap jenjang pendidikan. Pembelajaran akan berjalan dengan baik apabila disiapkan secara matang. Upaya perbaikan kualitas pendidikan di perguruan tinggipun gencar dilakukan. Implementasi kurikulum berbasis KKNI diharapkan akan menghasilkan calon generasi masa depan yang mempunyai kompetensi sesuai tuntutan abad 21.
Tuntutan abad 21 adalah kualitas manusia yang mampu menerapkan metode ilmiah dalam menggunakan pengetahuan dan menciptakan pengetahuan baru. Keterampilan tersebut dapat dilatihkan melalui pembelajaran IPA.

IPA merupakan salah satu muatan pelajaran yang diajarkan di setiap jenjang perguruan tinggi. Pembelajaran IPA memungkinakan mahasiswa untuk mempunyai kemampuan berpikir tingkat tinggi 
yang diwujudkan dalam produk, sikap dan proses.

Mahasiswa harus memiliki kemampuan proses sains. Kemampuan proses sains merupakan sebuah keterampilan untuk menerapkan konsep, prinsip, hukum, dan teori sains, baik berupa keterampilan mental, keterampilan fisik (manual) maupun keterampilan sosial (Wolfinger, 1994). Kemampuan ini dibutuhkan dalam menyelesaikan masalah pribadi, keilmuan, sosial, dan berbagai masalah praktis secara efektif. Oleh karena itu, pendidik perlu memperhatikan pemilihan model pembelajaran yang tepat untuk menciptakan pembelajaran yang efektif (Fanny, 2019).

Hasil penelitian sebelumnya tentang literasi sains menunjukkan bahwa kemampuan literasi sains mahasiswa PGSD Angkatan 2017 masih dalam kategori level 2 (Juniarso, 2019). Rendahnya hasil literasi sains tersebut menunjukkan bahwa keterampilan proses sains mahasiswa masih perlu menjadi perhatian.

Pendidik sains diharapkan untuk menciptakan pembelajaran yang menekankan siswanya untuk memahami konsep-konsep dan kemampuan proses sains dibandingkan hanya hanya menghafal fakta atau informasi. Salah satu alternatif model pembelajaran yang dapat digunakan adalah problem based learning.
Problem based learning menekankan pada pembelajaran berbasis masalah kontekstual sehingga mampu membuat siswa terlatih menyelesaikan masalah dan menemukan pengetahuan konsep melalui apa yang dipelajari (Barbara, Groh, and Allen 2001). Penelitian Kurniahtunnisa (2016) dan Yustitia (2019) juga menyatakan bahwa PBL membuat kemampuan berpikir siswa menjadi lebih baik.

Melalui pembelajaran PBL, aktivitas siswapun menjadi lebih baik. Siswa melakukan pembelajaran aktif yang menumbuhkan motivasi belajar sehingga berdampak pada hasil belajar siswanya. Hal ini sejalan dengan hasil penelitian Nafiah dan Suyanto (2014) yang mengatakan bahwa implementasi PBL dapat meningkatkan hasil belajar siswa.

Merujuk pada pemaparan di atas, peneliti melakukan penelitian untuk mengetahui keefektifan model PBL terhadap kemampuan proses sains mahasiswa PGSD.

\section{METODE PENELITIAN}

Penelitian dilaksanakan di Program Studi Pendidikan Guru Sekolah Dasar (PGSD) Unipa Surabaya. Penelitian ini merupakan penelitian kuasi eksperimen. Desain yang digunakan adalah posttest only control design (Creswell, 2017). Melalui penelitian eksperimental, penelitian ini bertujuan untuk mengetahui keefektifan model PBL 
terhadap kemampuan literasi sains mahasiswa PGSD.

Populasinya adalah seluruh mahasiswa PGSD regular Angkatan 2018 yang memperoleh Mata Kuliah Konsep IPA. Populasi terdiri atas 7 kelas paralel, yaitu kelas A sampai G. Teknik sampling yang digunakan adalah random sampling. Sampel penelitian yang digunakan dalam penelitian ini adalah kelas $A$ sebagai kelas eksperimen dan kelas $C$ sebagai kelas kotrol. Kelas A menerapkan model PBL, sedangkan kelas C menerapkan model pembelajaran konvensional (ceramah dosen).

Keefektifan dalam penelitian ini artinya kemampuan proses sains mahasiswa di kelas eksperimen tidak sama dengan kelas kontrol dan aktivitas pembelajaran di kelas eksperimen kategorinya aktif.

Metode tes digunakan untuk memperoleh data kemampuan literasi sains, sedangkan metode observasi untuk data aktivitas siswa di kelas eksperimen. Instrumen yang digunakan adalah soal tes uraian literasi sains yang terdiri dari 5 butir. Instrumen aktifitas mahasiswa berupa lembar observasi dengan pertanyaan terbuka. Observer terdiri atas 2 rekan sejawat peneliti.

Analisis data tes menggunakan uji kesamaan rerata. Analisis data observasi aktivitas mahasiswa menggunakan statistika deskriptif.

\section{HASIL PENELITIAN DAN \\ PEMBAHASAN}

Sebelum melakukan penelitian, eksperimen peneliti mengumpulkan data awal berupa nilai UTS pada Mata Kuliah IPA. Data UTS ini digunakan untuk memastikan bahwa kondisi awal kelas eksperimen homogen.

Data awal populasi (nilai berupa nilai UTS tersebut dianalisis menggunakan uji keseimbangan (uji t dua pihak). Uji prasyarat menggunakan uji normalitas dan uji homogenitas.

Berdasarkan data awal diperoleh bahwa data berasal dari data berdistribusi normal. Variansinyapun homogen. Melalui random sampling terpilih dua kelas, yaitu kelas A sebagai kelas eksperimen dan kelas $C$ sebagai kelas kontrol. Setelah terpilih dua kelas, peneliti melakukan pembelajaran PBL di kelas A. Pembelajaran dilakukan sesuai dengan sintaks model pembelajaran PBL. Setelah diberi perlakuan sebanyak tiga pertemuan, peneliti memberikan tes kemampuan proses sains.

Tes dibuat sendiri oleh peneliti. Tes berupa soal uraian dan kisi-kisi disesuaikan dengan indikator kemampuan proses sains. Sebelum soal diberikan tes divalidasi oleh ahli, kemudian diujicobakan di kelas F. Hasil uji coba menyatakan bahwa tes valid dan reliabel.

Selain memberikan tes pada akhir pembelajaran, peneliti juga melakukan observasi aktivitas 
mahasiswa yang diajar menggunakan PBL. Lembar observasi disesuaikan dengan indikator aktivitas siswa (aktivitas oral, visual, dan writing). Observer pada penelitian ini adalah dua rekan sejawat.

Hasil tes kemampuan proses sains menunjukkan bahwa rerata nilai kelas eksprimen lebih baik daripada kelas kontrol. Deskripsi ditunjukkan Tabel 1 berikut.

Tabel 1. Deskripsi Hasil Tes

\begin{tabular}{ccc}
\hline & Kelas A & Kelas C \\
\hline Rerata & 76,24 & 72,81 \\
\hline $\begin{array}{c}\text { Nilai } \\
\text { Maks }\end{array}$ & 96 & 93 \\
\hline Nilai Min & 50 & 37 \\
\hline
\end{tabular}

Berikut hasil uji normalitas data tes kemampuan proses sains.

Tabel 2. Hasil Uji Normalitas

\begin{tabular}{ccc}
\hline & Kelas A & Kelas C \\
\hline $\mathbf{X}^{2}$ hitung & 5,26 & 2,27 \\
\hline $\mathbf{X}^{2}$ tabel & 7,81 & 7,81 \\
\hline Kriteria & $\begin{array}{c}\text { Berdistribusi } \\
\text { normal }\end{array}$ & $\begin{array}{c}\text { Berdistribusi } \\
\text { normal }\end{array}$ \\
\hline
\end{tabular}

Berikut hasil uji homogenitas data tes kemampuan proses sains.

Tabel 3. Hasil Uji Homogenitas

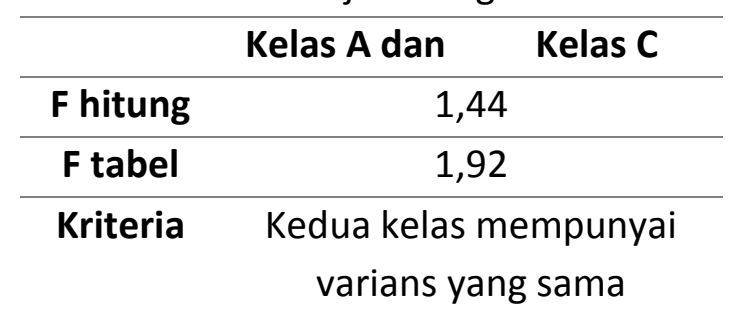

Berikut hasil uji kesamaan dua rerata data tes kemampuan proses sains.

Tabel 4. Hasil Uji Kesamaan Dua Rerata

\begin{tabular}{ccc}
\hline & Kelas A & Kelas C \\
\hline Rerata & 76,24 & 72,81 \\
\hline $\mathbf{N}$ & 36 & 40 \\
\hline T Hitung & \multicolumn{2}{c}{2,86} \\
\hline T tabel & \multicolumn{2}{c}{1,993} \\
\hline Kriteria & $\begin{array}{c}\text { Rerata kelas } \\
\text { eksperimen tidak } \\
\text { sama dengan kelas } \\
\text { kontrol }\end{array}$ \\
\hline
\end{tabular}

Berdasarkan Tabel 4 di atas, rerata kelas A adalah 76,24, sedangkan rerat kelas kontrol 72,81. $\mathrm{Hal}$ tersebut menunjukkan bahwa kemampuan proses sains kelas eksperimen lebih baik dengan kelas kontrol. Hasil ini sejalan dengan hasil penelitian (Setiani 2016) yang menyatakan bahwa PBL mampu berpengaruh positif terhadap kemampuan literasi sains siswa SMA Kelas X. Melalui PBL mahasiswa diberi tanggung jawab untuk menjadi seorang problem solver yang secara langsung melakukan proses belajar (Hoogland et al. 2018).

$$
\text { Pembelajaran di kelas }
$$
eksperimen dilakukan sesuai sintaks model PBL, yaitu (1) mahasiswa diorientasikan pada masalah terkait sains. Materi yang digunakan adalah system peredaran darah; 
mahasiswa diorganisasikan untuk berpikir tentang solusi masalah yang diberikan; (3) mahasiswa dibimbing untuk melakukan penyelidikan secara individua tau kelompok; (4) mahasiswa diarahkan untuk menyajikan hasil diskusinya; (5) mahasiswa menganalisis dan mengevaluasi proses penyelesaian masalah.

Aktivitas siswa di kelas eksperimen termasuk kategori aktif. Mahasiswa aktif dalam aktivitas oral, ditunjukkan melalui aktivitas tanya jawab saat proses diskusi. Masingmasing kelompok memberi pendapat dan tidak ragu untuk melakukan debat jika ada hal yang dirasa kurang tepat. Mahasiswa aktif dalam aktivitas visual, ditunjukkan melalui memperhatikan instruksi dosen dan membaca hasil diskusi di depan kelas. Mahasiswa aktif dalam aktivitas writing, ditunjukkan melalui keaktifan $72 \%$ mahasiswa mencatat hasil diskusi tentang penyelesaian masalah pada materi sistem pernapasan. Mahasiswa juga aktif membuat laporan tentang kesimpulan atau refleksi penemuan konsep. Hal penelitian yang dilakukan sesuai beberapa pendapat yang menyatakan bahwa penerapan PBL dapat membuat aktivitas siswa meningkat (Anwar dan Jurotun, 2019; Shofiyah dan Wulandari; 2018).

\section{SIMPULAN}

Hasil penelitian menyatakan bahwa model PBL efektif terhadap kemampuan literasi sains. Keefektifan ditunjukkan dari hasil tes kemampuan proses sains mahasiswa kelas yang diajar menggunakan PBL tidak sama dengan yang diajar menggunakan model konvensional/ceramah dosen. dan observasi. Aktivitas mahasiswa yang diajar menggunakan PBL menunjukkan kategori aktif.

Berdasarkan hasil penelitian ini, peneliti menyarankan agar dosen/ pendidik sebaiknya menerapkan PBL sebagai upaya perbaikan kemampuan proses sains.

\section{DAFTAR PUSTAKA}

Anwar, Khoirul, and Jurotun Jurotun. 2019. "Peningkatan Aktivitas Dan Hasil Belajar Siswa SMA Pada Dimensi Tiga Melalui Model Pembelajaran PBL Berbantuan Alat Peraga." Kreano, Jurnal Matematika Kreatif-Inovatif 10(1): 94-104.

Barbara J. Duch, Susan E. Groh, and Deborah E. Allen. 2001. The Power of Problem Based Learning.

Creswell, J. W., \& Creswell, J. D. (2017). Research design: Qualitative, quantitative, and mixed methods approaches. Sage publications. 
Hoogland, Kees, Birgit Pepin, Jaap De Koning, and Arthur Bakker. 2018. "Research in Mathematics Education Word Problems versus Image-Rich Problems: An Analysis of Effects of Task Characteristics on Students ' Performance on Contextual Mathematics Problems." 4802.

Fanny, A. M. (2019, March). Analysis Of Pedagogical Skills And Readiness Of Elementary School Teachers In Support of The Implementation of The 2013 Curriculum. In International Conference on Bussiness Law and Pedagogy (Vol. 1, No. 1, pp. 5963).

Juniarso, T. (2019). Kemampuan Literasi Sains Mahasiswa PGSD Universitas PGRI Adi Buana Surabaya. Trapsila: Jurnal Pendidikan Dasar, 1(01), 1-7.

Kurniahtunnisa. 2016. "Pengaruh Model Problem Based Learning Terhadap Kemampuan Berpikir Kritis Siswa Materi Sistem Ekskresi." Journal of Biology Education 5(3): 310-18.

Nafiah, Yunin Nurun, and Wardan Suyanto. 2014. "Penerapan Model Problem-Based Learning Untuk Meningkatkan Keterampilan Berpikir Kritis Dan Hasil Belajar Siswa." Jurnal Pendidikan Vokasi 4(1): 125-143.
Setiani, Hani; Ngazizah, Nur; Kurniawan, Eko Setyadi. 2016. "Efektivitas Model Pembelajaran Problem Based Learning Terhadap Kemampuan Literasi Sains Siswa Kelas X SMA Negeri 10 Purworejo Tahun Pelajaran 2015/2016." RADIASI: Jurnal Berkala Pendidikan Fisika 9(1): 7-12.

Wolfinger, Donna M.. 1994. Science and Mathematics In Early Childhood Education. New York: Harper Collins College Publisher

Yustitia, Via. 2019. “Problem Based Learning pada literasi Matematika: Studi Kuasi Eksperimental pada Mahasiswa PGSD." Jurnal Union 7(31): 347352. 